\title{
A Cameroonian Study on Mixing Concrete with Wood Ashes: Effects of 0-30\% Wood Ashes as a Substitute of Cement on the Strength of Concretes
}

\author{
Théodore Gautier L.J. Bikoko \\ Department of Civil Engineering Science, University of Johannesburg, P O Box 524, Auckland Park 2006, Johannesburg, \\ South Africa
}

Corresponding Author Email: lejeunegautier@rocketmail.com

https://doi.org/10.18280/rcma.310502

Received: 25 Janaury 2021

Accepted: 19 May 2021

\section{Keywords:}

avocado ash, eucalyptus ash, cement, compressive strength, concrete

\begin{abstract}
To fight against the high cost and the increasing scarcity of cement and at the same time to reduce the $\mathrm{CO}_{2}$ greenhouse gases emission associated with the production of Portland cement, two types of wood ashes as a substitute of cement in the production of concretes were investigated. In this paper, we substituted cement by two types of species of wood ashes namely, avocado and eucalyptus ashes following the proportions ranging from $0 \%$ to $30 \%$ on one hand, and on the other hand, we added these two types of species of wood ashes namely, avocado and eucalyptus ashes following the proportions ranging from $0 \%$ to $10 \%$ by weight of cement in the concrete samples. After 7, 14 and 28 days of curing, compressive strength tests were conducted on these concrete samples. The findings revealed that using wood ashes as additives/admixtures or as a substitute of cement in the production/manufacturing of concrete decreased the compressive strength of concrete. Hence, it can be said that wood ash has a negative influence on the strength of concrete. At three percent (3\%) and ten percent (10\%) of addition, the wood ash from eucalyptus specie offers better resistance compared to the wood ash from avocado specie, whereas at five percent $(5 \%)$ of addition, the wood ash from avocado specie offers better resistance compared to the wood ash from eucalyptus specie. At thirty percent (30\%) of substitution, the wood ash from eucalyptus specie offers better resistance compared to the wood ash from avocado specie. The compressive strengths increase with the increase of curing age.
\end{abstract}

\section{INTRODUCTION}

The increase of the population creates a need for housing and civil engineering infrastructures such as roads, bridges, viaducts, airports, railways, dams, walkways, pools, stadia etc. especially in developing countries like Cameroon. This evidently creates high demand in Portland cement clinker, cement-based materials e.g., mortar, concrete and cement paste [1-3] and consequently continuous the $\mathrm{CO}_{2}$ greenhouse gas emission by the cement industry $[4,5]$ and the cement industry represents $5-7 \%$ of all manmade emissions of $\mathrm{CO}_{2}$ [610], the primary greenhouse gas that drives global climate change $[10,11]$. It was reported that the production of one ton of cement generates 0.55 tons of $\mathrm{CO}_{2}$ related to the calcination of raw materials and an additional 0.39 tons of $\mathrm{CO}_{2}$ related to the fuels (coal, fuel oil) needed for cooking and grinding, which represents a total of 0.94 tonnes of $\mathrm{CO}_{2}$ per ton of cement [12]. In the same vein, Chowdhury et al. [13] also have reported that for every $600 \mathrm{~kg}$ of cement, approximately 400 $\mathrm{kg}$ of $\mathrm{CO}_{2}$ is released into the atmosphere. It is reported in the literatures [14-17] that Portland cement is the second most used substance in the world after water and it is a key component and the most important ingredient in the manufacturing of concrete and mortar and most expensive ingredient in concrete and mortar. Pehlivan et al. [18] stated also that cement is the most widely used binding material in concrete mixtures and concrete is no more than a mixture of cement, water, aggregate (fine and coarse) and admixture [19, 20]. Previous researches have demonstrated that more than 1 $\mathrm{m}^{3}$ of concrete is produced per individual per year worldwide [10]. To contribute to the reduction of the use of costly Portland cement in concretes and mortars, and at the same time to reduce the $\mathrm{CO}_{2}$ greenhouse gases emission associated with the production of Portland cement, two types of wood ashes namely, Eucalyptus ash and Avocado ash as a substitute of cement in the production of concretes were investigated in the present study.

It is reported that wood is the third consumption building materials next to cement and the world statistical review report stated that in 2015, the global cement produced was 4,6 billion tonnes and it is expected values between 6 and 13.5 billion tonnes in 2050 [21]. This is equivalent to about $626 \mathrm{~kg} / \mathrm{per}$ capita, a value higher than the amount of human food consumption [17, 22]. Krausmann et al. [23] and Steinberger et al. [24] reported that in 2005, cement-based materials represented about $30 \%$ of the total global materials use including fossil fuels and in 1950; cement-based materials represented only $7 \%$. This has increased 4.285 times in only 55 years.

During the last two decades, many studies have been conducted on concrete, but very few were focused on mixing concrete with wood ashes [25]. Udoeyo et al. [25] mixed concrete with wood ash up to $30 \%$ by the weight of cement and found that the mechanical strengths were reduced by 9 - 
$38 \%$ for mixtures that incorporated high levels of wood ash. Wang et al. [26] stated that partial replacement of cement by wood ash in concrete impact slightly the early age compressive strength of concrete.

To the best knowledge of the author, this is the first study in Cameroon focusing on mixing concrete with wood ashes namely, avocado ash and eucalyptus ash.

\section{MATERIALS AND METHODS}

\subsection{Materials}

Cement, sand, gravel, avocado ashes, eucalyptus ashes and water were the materials used in this study. The materials are discussed as follows:

\subsubsection{Cement}

CN CEM II/B-P 42.5 R conforming to the Cameroonian standard (NC 234: 2009-06) was used for the study. Cement sample is shown in Figure 5(a). Table 1 presents physical and mechanical characteristics. Its chemical composition is listed in Table 2; Table 3 summarizes its mineralogical composition. Its chemical composition was given by DANGOTE (Producer).

Table 1. Physical and mechanical characteristics of Portland cement (NC CEM II/ B-P 42.5R) used [14, 16]

\begin{tabular}{cc}
\hline Characteristics & NC CEM II/ B-P 42.5 R \\
\hline Apparent density $\left(\mathrm{g} / \mathrm{cm}^{3}\right)$ & Not specified \\
Absolute density $\left(\mathrm{g} / \mathrm{cm}^{3}\right)$ & Not specified \\
Fineness $\left(\mathrm{cm}^{2} / \mathrm{g}\right)$ & $3900-4000$ \\
Initial setting time $(\mathrm{min})$ & $\geq 60$ \\
Expansion- (Soundness) $(\mathrm{mm})$ & $\leq 10$ \\
Compressive strength at & $\geq 20$ \\
2 days (MPa) & $\geq 42.5$ \\
Compressive strength at & $\leq 62.5$ \\
28 days (MPa) & \\
\hline
\end{tabular}

Table 2. Chemical composition of Portland cement (NC CEM II/ B-P 42.5R) used

\begin{tabular}{cc}
\hline Oxides & Content, (\%) \\
\hline $\mathrm{SiO}_{2}$ & 21.50 \\
$\mathrm{Al}_{2} \mathrm{O}_{3}$ & 6.05 \\
$\mathrm{Fe}_{2} \mathrm{O}_{3}$ & 3.94 \\
$\mathrm{CaO}$ & 51.6 \\
$\mathrm{MnO}$ & 0.08 \\
$\mathrm{MgO}$ & 5.0 \\
$\mathrm{~K}_{2} \mathrm{O}$ & 1.23 \\
$\mathrm{TiO}_{2}$ & 1.12 \\
$\mathrm{Na}_{2} \mathrm{O}$ & 1.09 \\
$\mathrm{SO}_{3}$ & 3.5 \\
$\mathrm{P}_{2} \mathrm{O}_{5}$ & 0.21 \\
$\mathrm{SrO}$ & 0.46 \\
$\mathrm{Cl}$ & 0.02 \\
\hline
\end{tabular}

Table 3. Mineralogical composition of Portland cement (NC CEM II/ B-P 42.5R) used [14, 16]

\begin{tabular}{cc}
\hline \multicolumn{2}{c}{ Mineralogical composition of Portland cement (\%): NC CEM II/ } \\
B-P 42.5R \\
\hline Main constituents & $(\%)$ \\
Clinker & $65-79$ \\
Secondary constituents & $(\%)$ \\
Pozzolana & $21-35$ \\
Gypsum & $\leq 5 \%$ \\
\hline
\end{tabular}

\subsubsection{Sand River (fine sand)}

The fine sand (0/4) used was from Wum in the North West region of Cameroon, Bamenda. Figure 1 show its particle size distribution curve with maximum size of $4 \mathrm{~mm}$. Its fineness modulus is 1.431 .

\subsubsection{Gravel $(0 / 16)$}

The (0/16) gravel used was from the quarry of GEOSTRUCT Construction Company, Mile 4 Nkwen in the North West region of Cameroon, Bamenda. Its particle size distribution curve is shown in Figure 2 with maximum size of $16 \mathrm{~mm}$.

\subsubsection{Gravel (14/25)}

The (14/25) gravel used was also from the quarry of GEOSTRUCT Construction Company, Mile 4 Nkwen in the North West region of Cameroon, Bamenda. Its particle size distribution curve is shown in Figure 3 with maximum size of $25 \mathrm{~mm}$.

The aggregate appearances are shown in Figure 4.

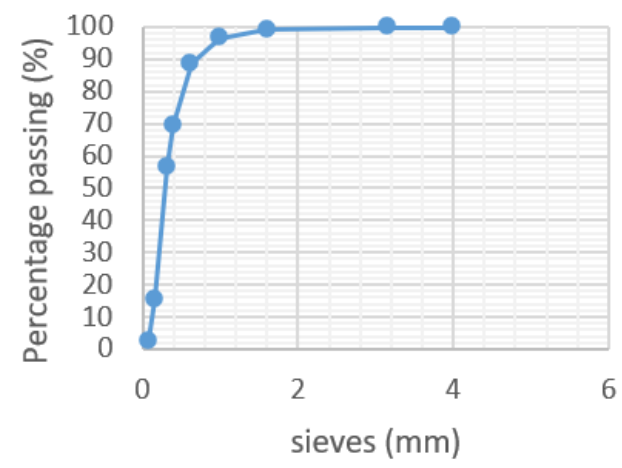

Figure 1. Particle size distribution curve of river Sand

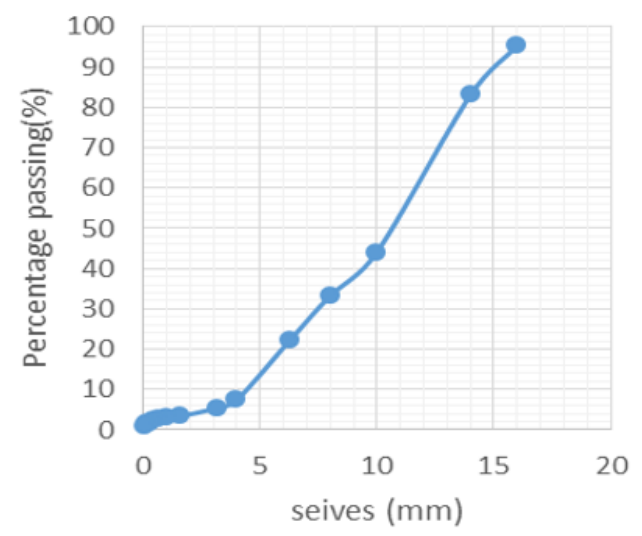

Figure 2. Particle size distribution curve of fine gravel 1

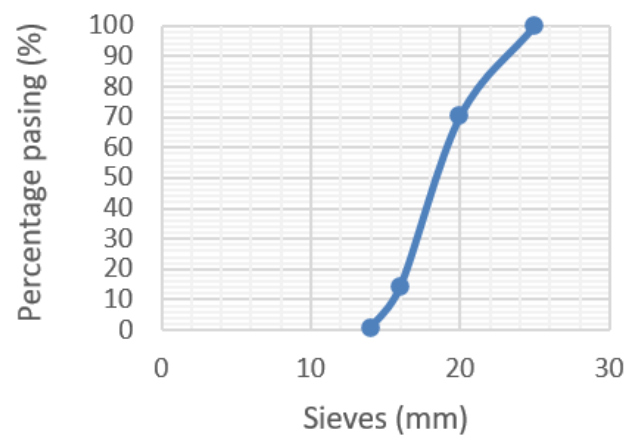

Figure 3. Particle size distribution curve of coarse gravel 2 


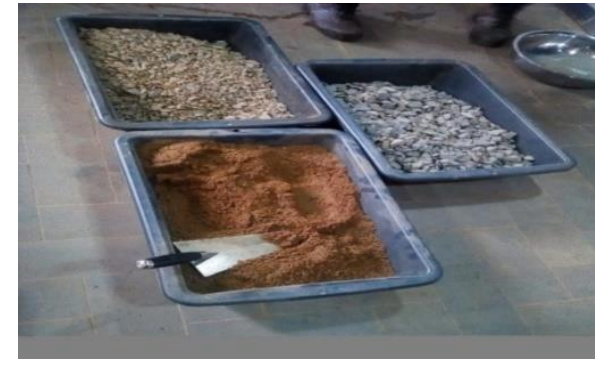

Figure 4. Aggregate appearances

\subsubsection{Wood ashes}

The avocado ashes used were also obtained in a household in Bambili in the North West region of Cameroon. Table 4 reports its chemical compositions. It can be observed from Table 4 that the sum of $\left(\mathrm{SiO}_{2}+\mathrm{Al}_{2} \mathrm{O}_{3}+\mathrm{Fe}_{2} \mathrm{O}_{3}\right)=6.5 \%$ which is less than $70 \%$ the minimum amount according to ASTMC618-15 [27] to a material qualify having pozzolanic properties. Hence, the avocado ashes used haven't pozzolanic properties. Its alkali content $\left(\% \mathrm{Na}_{2} \mathrm{O}+0.658 \times \% \mathrm{~K}_{2} \mathrm{O}\right)$ is equal to $7.34 \%$. The Eucalyptus ashes used were collected in a traditional bakery in mile 4 Nkwen in the North West region of Cameroon. Table 5 presents its chemical compositions. It can be seen from Table 5 that the sum of $\left(\mathrm{SiO}_{2}+\mathrm{Al}_{2} \mathrm{O}_{3}+\right.$ $\left.\mathrm{Fe}_{2} \mathrm{O}_{3}\right)=7.45 \%$ which is less than $70 \%$ the minimum amount according to ASTMC618-15 [27] to a material qualify having pozzolanic properties. Hence, the eucalyptus ashes used haven't pozzolanic properties. Its alkali content $\left(\% \mathrm{Na}_{2} \mathrm{O}+\right.$ $0.658 \times \% \mathrm{~K}_{2} \mathrm{O}$ ) is equal to $4.08 \%$. It can be seen in Table 4 and Table 5 that the most abundant oxides of the Avocado ash and Eucalyptus ash samples were: $\mathrm{CaO}$ with $72.89 \%$ and $77.31 \%$, respectively, $\mathrm{K} 2 \mathrm{O}$ with $10.87 \%$ and $5.92 \%$, respectively and $\mathrm{MgO}$ with $6.65 \%$ and $4.51 \%$, respectively. Other oxides like $\mathrm{SiO} 2, \mathrm{Al} 2 \mathrm{O} 3, \mathrm{Fe} 2 \mathrm{O} 3$ etc. were also present in the Avocado ash and Eucalyptus ash samples. Physical appearances of Avocado ashes and Eucalyptus ashes are shown in Figure 5(b) and Figure 5(c), respectively.

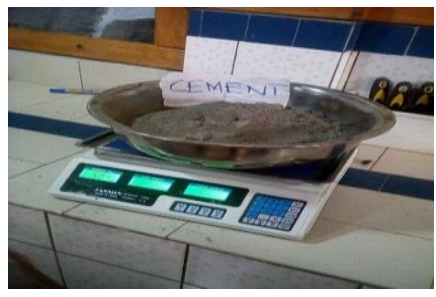

(a)

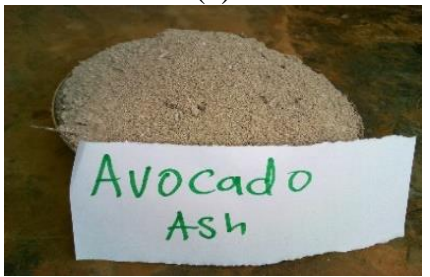

(b)

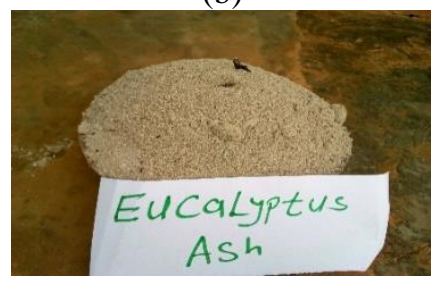

(c)

Figure 5. (a) Cement; (b) Avocado ash; (c) Eucalyptus Ash
Table 4. Chemical composition of Avocado ashes

\begin{tabular}{cc}
\hline Chemical compounds & Concentration \% \\
\hline $\mathrm{CaO}$ & 72.89 \\
$\mathrm{~K} 2 \mathrm{O}$ & 10.87 \\
$\mathrm{MgO}$ & 6.65 \\
$\mathrm{SiO}_{2}$ & 3.57 \\
$\mathrm{Fe}_{2} \mathrm{O}_{3}$ & 1.60 \\
$\mathrm{Al}_{2} \mathrm{O}_{3}$ & 1.33 \\
$\mathrm{SrO}$ & 0.56 \\
$\mathrm{MnO}$ & 0.45 \\
$\mathrm{Cl}$ & 0.37 \\
$\mathrm{P}_{2} \mathrm{O}_{5}$ & 0.31 \\
$\mathrm{SO}_{3}$ & 0.27 \\
$\mathrm{TiO}_{2}$ & 0.22 \\
$\mathrm{Na}_{2} \mathrm{O}$ & 0.19 \\
$\mathrm{SiO}_{2}+\mathrm{Al}_{2} \mathrm{O}_{3}+\mathrm{Fe}_{2} \mathrm{O}_{3}$ & 6.5 \\
\hline
\end{tabular}

Table 5. Chemical composition of Eucalyptus ashes

\begin{tabular}{cc}
\hline Chemical compounds & Concentration \% \\
\hline $\mathrm{CaO}$ & 77.31 \\
$\mathrm{~K}_{2} \mathrm{O}$ & 5.92 \\
$\mathrm{MgO}$ & 4.51 \\
$\mathrm{Fe}_{2} \mathrm{O}_{3}$ & 3.03 \\
$\mathrm{SiO}_{2}$ & 2.51 \\
$\mathrm{Al}_{2} \mathrm{O}_{3}$ & 1.91 \\
$\mathrm{P}_{2} \mathrm{O}_{5}$ & 1.31 \\
$\mathrm{Na} 2$ & 0.73 \\
$\mathrm{MnO}$ & 0.62 \\
$\mathrm{Cl}$ & 0.62 \\
$\mathrm{SrO}$ & 0.47 \\
$\mathrm{SO}_{3}$ & 0.38 \\
$\mathrm{TiO}_{2}$ & 0.38 \\
$\mathrm{SiO}_{2}+\mathrm{Al}_{2} \mathrm{O}_{3}+\mathrm{Fe}_{2} \mathrm{O}_{3}$ & 7.45 \\
\hline
\end{tabular}

\subsubsection{Mixing water}

The water to be used in the preparation of concrete must meet a certain degree of portability, namely, it must not contain suspended solids, chemicals such as acids etc. The water that I used for our formulations was from the Laboratory GEOSTRUCT tap (Figure 6) (CAMWATER) of Bamenda, Cameroon.

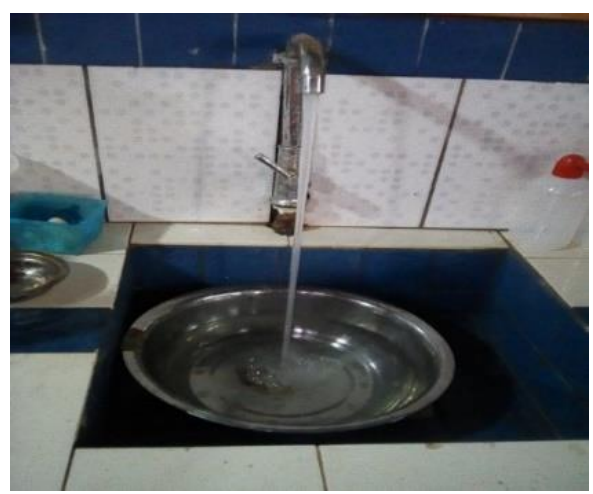

Figure 6. Mixing water

\subsection{Methods}

\subsubsection{Sample preparation, casting and curing}

The samples were prepared as follows: the dry constituents i.e. sand, gravel1, gravel 2 and then the wood ashes i.e. avocado ash and eucalyptus ash and finally the Portland cement were first mixed. Then, we added water and we poured the fresh concretes into cylindrical moulds. Each mould was filled respectively with two layers of fresh concrete randomly 
compacted. Each layer was tamped with the tamping rod [3]. After casting, the concrete samples were demoulded after 24 hours and immersed in a watertight container filled with water for curing as shown in Figure 7. After that, the concrete specimens were removed from the container and stored in a curing room at $20 \pm 1^{\circ} \mathrm{C}$ and $95 \%$ humidity for 24 hours before crushing. The mix proportions are shown in Tables $6,7,8$ and 9 (All the formulations are made for $1 \mathrm{~m}^{3}$ of concrete).

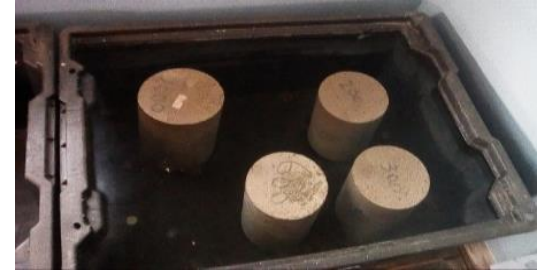

Figure 7. Immersion of concrete specimens for curing

Table 6. Mix proportioning of the formulation with addition of avocado ashes in concrete

\begin{tabular}{ccccc}
\hline Materials (kg) & Control & 3\% avocado ashes & $5 \%$ avocado ashes & 10\% avocado ashes \\
\hline Cement & 320 & 320 & 320 & 320 \\
River sand (0/5) (kg) & 563 & 563 & 563 & 563 \\
Gravel (0/16) & 199 & 199 & 199 & 199 \\
Gravel (14/25) & 1065.94 & 1065.94 & 1065.94 & 1065.94 \\
Water & 198.43 & 198.43 & 198.43 & 198.43 \\
Avocado ashes & 0 & 9.6 & 16 & 32 \\
\hline
\end{tabular}

Table 7. Mix proportioning of the formulation with addition of eucalyptus ashes in concrete

\begin{tabular}{ccccc}
\hline Materials (kg) & Control & 3\% eucalyptus ashes & 5\% eucalyptus ashes & 10\% eucalyptus ashes \\
\hline Cement $(\mathbf{k g})$ & 320 & 320 & 320 & 320 \\
River sand (0/5) $\mathbf{( k g )}$ & 563 & 563 & 563 & 563 \\
Gravel (0/16) & 199 & 199 & 199 & 199 \\
Gravel (14/25) & 1065.94 & 1065.94 & 1065.94 & 1065.94 \\
Water & 198.43 & 198.43 & 198.43 & 198.43 \\
Eucalyptus ashes & 0 & 9.6 & 16 & 32 \\
\hline
\end{tabular}

Table 8. Mix proportioning for the partial substitution of Portland cement with avocado ashes in concrete

\begin{tabular}{ccccc}
\hline Materials (kg) & Control & 10\% avocado ashes & 20\% avocado ashes & 30\% avocado ashes \\
\hline Cement $(\mathrm{kg})$ & 320 & 288 & 256 & 224 \\
River sand (0/5) & 563 & 563 & 563 & 563 \\
Gravel (0/16) & 199 & 199 & 199 & 199 \\
Gravel (14/25) & 1065.94 & 1065.94 & 1065.94 & 1065.94 \\
Water & 198.43 & 198.43 & 198.43 & 198.43 \\
Avocado ashes & 0 & 32 & 64 & 96 \\
\hline
\end{tabular}

Table 9. Mix proportioning for the partial substitution of Portland cement with eucalyptus ashes in concrete

\begin{tabular}{ccccc}
\hline Materials & Control & 10\% eucalyptus ashes & 20\% eucalyptus ashes & 30\% eucalyptus ashes \\
\hline Cement $(\mathrm{kg})$ & 320 & 288 & 256 & 224 \\
River sand $(0 / 5)(\mathrm{kg})$ & 563 & 563 & 563 & 563 \\
Gravel 0/16(kg) & 199 & 199 & 199 & 199 \\
Gravel 14/25(kg) & 1065.94 & 1065.94 & 1065.94 & 1065.94 \\
Water $(\mathrm{kg})$ & 198.43 & 198.43 & 198.43 & 198.43 \\
Eucalyptus ashes $(\mathrm{kg})$ & 0 & 32 & 64 & 96 \\
\hline
\end{tabular}

\subsubsection{XRF analysis}

The chemical characteristics of the woody ashes used were determined using the X-ray fluorescence (XRF) analyser by Philips. Test samples consisted of discs of diameter of $68 \pm 2$ $\mathrm{mm}$ and thickness of $25 \pm 2 \mathrm{~mm}$.

\subsubsection{Compression tests}

The compressive strength tests were used to determine the compressive strength of the concrete specimens. The concrete specimens at 7, 14 and 28 days of maturity were mounted on to the universal compression testing machine at $1 \mathrm{~mm} / \mathrm{min}$ crosshead speed (Emic DL10000) (see Figure 8), which has a load capacity of 300 ton. The compressive strengths of the concrete specimens were calculated using Eq. (1).

$$
\boldsymbol{\sigma}=\mathrm{F} / \mathrm{S}
$$

where: $\boldsymbol{\sigma}=$ compressive strength, $\mathrm{F}=$ maximum load applied before failure, $\mathrm{S}=$ cross sectional area of the specimen.

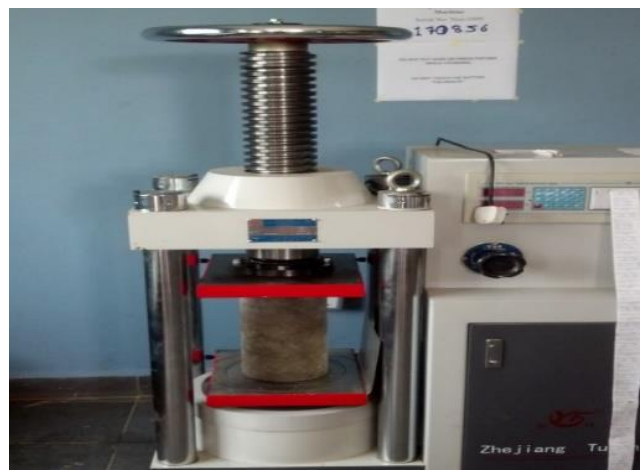

Figure 8. Compressive strength testing machine $[14,16]$ 


\section{RESULTS AND DISCUSSIONS}

Figure 9 reports the compressive strength results of concretes as a function of curing ages of 7, 14 and 28 days at $0 \%, 3 \%, 5 \%$ and $10 \%$ addition of avocado ash and eucalyptus ash, respectively. The control (CO) specimens have the compressive strengths greater than those containing wood ashes i.e. avocado ash and eucalyptus ash. The compressive strengths of concretes increase with curing ages of 7, 14 and 28 days in all samples. It can be observed that the compressive strengths of $3 \%$ and $10 \%$ addition of eucalyptus ash are higher than those of $5 \%$ addition of avocado ash, whereas at $5 \%$ of addition, the compressive strength of avocado ash concrete are higher than the compressive strength of eucalyptus ash concrete.

In the legend of the Figure 9 the following notations represent: $\mathrm{CO}=$ Compressive strength of the control concrete; $\mathrm{CA}+3, \mathrm{CA}+5$ and $\mathrm{CA}+10=$ Compressive strength of concrete made with addition of $3 \%, 5 \%$ and $10 \%$ of avocado ash, respectively. $\mathrm{CE}+3, \mathrm{CE}+5$ and $\mathrm{CE}+10=$ Compressive strength of concrete made with addition of $3 \%, 5 \%$ and $10 \%$ of eucalyptus ash, respectively.

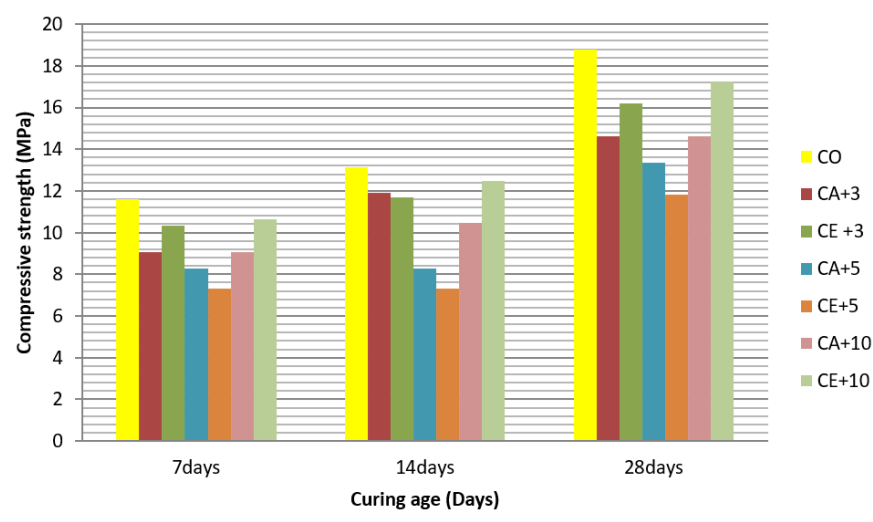

Figure 9. Compressive strength results of concretes as a function of curing ages of 7, 14 and 28 days at 3\%, 5\% and $10 \%$ addition of avocado ash and eucalyptus ash, respectively

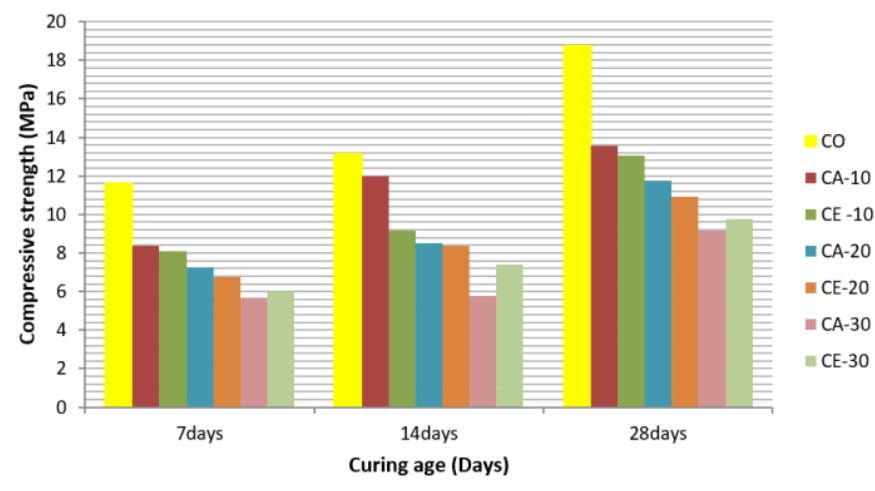

Figure 10. Compressive strength results of concretes as a function of curing ages of 7, 14 and 28 days at $10 \%, 20 \%$ and $30 \%$ substitution of avocado ash and eucalyptus ash, respectively

At curing age of 7 days, the compressive strength of the control specimen is $21.81 \%, 28.79 \%$ and $21.98 \%$ higher than that for mixtures incorporating $3 \%, 5 \%$ and $10 \%$ avocado ash, respectively as admixture/additive of Portland cement while at the same curing age, the compressive strength of the control specimen is $10.86 \%, 37.06 \%$ and $8.18 \%$ higher than that for mixtures incorporating 3\%, 5\% and $10 \%$ eucalyptus ash, respectively as admixture/additive of Portland cement. However, at curing age of 14 days, the compressive strength of the control specimen is $9.35 \%, 12.92 \%$ and $20.38 \%$ higher than that for mixtures incorporating $3 \%, 5 \%$ and $10 \%$ of avocado ash, respectively as admixture/additive of Portland cement while at the same curing age, the compressive strength of the control specimen is $11.10 \%, 18.70 \%$ and $5.17 \%$ higher than that for mixtures incorporating 3\%, 5\% and $10 \%$ eucalyptus ash, respectively as admixture/additive of Portland cement. On the other hand, at curing age of 28 days, the compressive strength of the control specimen is $22 \%, 28.82 \%$ and $22 \%$ higher than that for mixtures incorporating 3\%, 5\% and $10 \%$ avocado ash, respectively as admixture/additive of Portland cement while at the same curing age, the compressive strength of the control specimen is $13.79 \%, 37.08 \%$ and $8.2 \%$ higher than that for mixtures incorporating 3\%, 5\% and $10 \%$ eucalyptus ash, respectively as admixture/additive of Portland cement. It appeared that $5 \%$ addition of wood ash would cause more reduction in the 28-day compressive strength.

The decrease in the compressive strength of concrete after adding wood ash in the concrete mixture revealed that the wood ash helped to deactivate the wood ash-Portland cement system. Yang et al. [28] attributed this strength reduction to the presence of unburned carbon which creates weak spots that facilitated cracking during loading.

In the legend of the Figure 10 the following notations represent: $\mathrm{CO}=$ Compressive strength of the control concrete; CA-10, CA-20 and CA-30 = Compressive strength of concrete made with substitution of $10 \%, 20 \%$ and $30 \%$ of avocado ash, respectively. CE-10, CE-20 and CE-30 = Compressive strength of concrete made with substitution of $10 \%, 20 \%$ and $30 \%$ of eucalyptus ash, respectively.

Figure 10 presents the compressive strength results of concretes as a function of curing ages of 7, 14 and 28 days at $0 \%, 10 \%, 20 \%$ and $30 \%$ substitution of avocado ash and eucalyptus ash, respectively.

The control (CO) specimens have the compressive strengths greater than those substituted by wood ashes i.e. avocado ash and eucalyptus ash and the compressive strength decreases with the increase of the percentage of wood ash as partial replacement of cement into the concrete mixture, this is due to the reduction of the quantity of the cementitious material content in the concrete and the ash content which does not work in favour of mechanical resistance [29]. Besides, partial replacing the cement content with wood ash reduces the cost and the $\mathrm{CO}_{2}$ greenhouse gases emission of the final product. The compressive strength of concrete increases with curing ages of 7, 14 and 28 days. It can also be seen that the compressive strength is a function of the type of specie of wood ash used, at low percentages of substitution i.e. at $10 \%$ and $20 \%$, the concrete made with avocado ash give higher compressive strength than the one made with eucalyptus ash. However, at higher percentage of substitution i.e. at 30\%, the concrete made with eucalyptus ash give higher compressive strength that the one made with avocado ash.

At curing age of 7 days, the compressive strength of the control specimen is $27.84 \%, 37.24 \%$ and $51.2 \%$ higher than that for mixtures incorporating $10 \%, 20 \%$ and $30 \%$ avocado ash, respectively as partial replacement of Portland cement while at the same curing age, the compressive strength of the control specimen is $30.34 \%, 41.81 \%$ and $48.1 \%$ higher than that for mixtures incorporating $10 \%, 20 \%$ and $30 \%$ eucalyptus ash, respectively as as partial replacement of Portland cement. 
However, at curing age of 14 days, the compressive strength of the control specimen is $8.9 \%, 35.36 \%$ and $56.12 \%$ higher than that for mixtures incorporating 10\%, 20\% and $30 \%$ avocado ash, respectively as partial replacement of Portland cement while at the same curing age, the compressive strength of the control specimen is $30.34 \%, 36.50 \%$ and $43.87 \%$ higher than that for mixtures incorporating 10\%, 20\% and $30 \%$ eucalyptus ash, respectively as as partial replacement of Portland cement. On the other hand, at curing age of 28 days, the compressive strength of the control specimen is $27.86 \%$, $37.29 \%$ and $51.25 \%$ higher than that for mixtures incorporating 10, 20 and $30 \%$ avocado ash, respectively as partial replacement of Portland cement while at the same curing age, the compressive strength of the control specimen is $30.36 \%, 41.82 \%$ and $48.1 \%$ higher than that for mixtures incorporating 10, 20 and 30\% eucalyptus ash, respectively as partial replacement of Portland cement.

It can also be observed that using wood ash to partially replace Portland cement reduced the compressive strength of concrete in all curing ages i.e. at 7, 14 and 28 days of curing

It is interesting to note that higher wood ash replacement would result in lower compressive strength of concrete [28]. Yang et al. [28] stated that the lower compressive strength of concrete recorded at higher wood ash replacement is because the wood ash used was neither self-cementing, nor pozzolanic. This is also because at high wood ash replacements i.e. $20 \%$ or $30 \%$, the cement reduction became dominant [28].

\subsection{Comparison between the compressive strengths of concretes made of avocado ash and eucalyptus ash}

Table 10 shows the comparison between the compressive strength results of concretes made with addition of avocado ash and eucalyptus ash at 7, 14 and 28 days of curing. For concrete mixtures made of $3 \%$ addition, the compressive strength of avocado ash concrete showed an increase of 0.23 $\mathrm{MPa}$ in 14 days and a decrease of $1.27 \mathrm{MPa}$ in 7 days, and 1.54 $\mathrm{MPa}$ in 28 days comparing to eucalyptus ash concrete samples. However, at $5 \%$ of addition, the compressive strength of avocado ash concrete showed an increase of $0.96 \mathrm{MPa}$ in 7 days, $0.76 \mathrm{MPa}$ in 14 days and $1.55 \mathrm{MPa}$ in 28 days comparing to eucalyptus ash concrete samples. On the other hand, at $10 \%$ of addition, the compressive strength of avocado ash concrete showed a decrease of $1.6 \mathrm{MPa}$ in 7 days, $2 \mathrm{MPa}$ in 14 days and $2.59 \mathrm{MPa}$ in 28 days comparing to eucalyptus ash concrete samples. This let us to say that the ashes of Eucalyptus would be the best additive than the ashes of Avocado specifically the $10 \%$ one.

Table 10. Comparison between the compressive strengths of concretes made with addition of avocado ash and eucalyptus ash at 7,14 and 28 days of curing

\begin{tabular}{cccccc}
\hline $\begin{array}{c}\text { Curing } \\
\text { age } \\
\text { (days) }\end{array}$ & $\begin{array}{c}\text { Addition } \\
\text { rate }(\%)\end{array}$ & $\begin{array}{c}\text { Compressive } \\
\text { strengths of control } \\
\text { concretes (CO) } \\
\text { (MPa) }\end{array}$ & $\begin{array}{c}\text { Compressive strengths of } \\
\text { concretes made with } \\
\text { addition of avocado ash } \\
\text { (CA) (MPa) }\end{array}$ & $\begin{array}{c}\text { Compressive strengths of } \\
\text { concretes made with } \\
\text { addition of eucalyptus ash } \\
\text { (CE) (MPa) }\end{array}$ & $\begin{array}{c}\text { Diff. between Compressive } \\
\text { strengths of concretes made with } \\
\text { addition of avocado ash (CA) } \\
\text { and eucalyptus ash CE (MPa) }\end{array}$ \\
\hline 7 & 3 & 11.60 & 9.07 & 10.34 & -1.27 \\
14 & 3 & 13.15 & 11.92 & 11.69 & 0.23 \\
28 & 3 & 18.77 & 14.64 & 16.18 & -1.54 \\
7 & 5 & 11.60 & 8.26 & 7.30 & 0.96 \\
14 & 5 & 13.15 & 11.45 & 10.69 & 0.76 \\
28 & 5 & 18.77 & 13.36 & 11.81 & 1.55 \\
7 & 10 & 11.60 & 9.05 & 10.65 & -1.6 \\
14 & 10 & 13.15 & 10.47 & 12.47 & -2 \\
28 & 10 & 18.77 & 14.64 & 17.23 & -2.59 \\
\hline
\end{tabular}

Table 11. Comparison between the compressive strengths of concretes made with substitution of cement by avocado ash and eucalyptus ash at 7, 14 and 28 days of curing

\begin{tabular}{|c|c|c|c|c|c|}
\hline $\begin{array}{l}\text { Curing age } \\
\text { (days) }\end{array}$ & Substitution rate $(\%)$ & $\begin{array}{c}\text { Compressive } \\
\text { strengths of control } \\
\text { concretes }(\mathrm{CO}) \\
(\mathrm{MPa})\end{array}$ & $\begin{array}{c}\text { Compressive } \\
\text { strengths of } \\
\text { concretes made with } \\
\text { substitution of } \\
\text { cement by avocado } \\
\text { ash }(\mathrm{CA})(\mathrm{MPa})\end{array}$ & $\begin{array}{c}\text { Compressive } \\
\text { strengths of } \\
\text { concretes made with } \\
\text { substitution of } \\
\text { cement by } \\
\text { eucalyptus ash (CE) } \\
(\mathrm{MPa})\end{array}$ & $\begin{array}{c}\text { Diff. between } \\
\text { Compressive strengths } \\
\text { of concretes made with } \\
\text { substitution of avocado } \\
\text { ash (CA) and } \\
\text { eucalyptus ash CE } \\
\text { (MPa) }\end{array}$ \\
\hline 7 & 10 & 11.60 & 8.37 & 8.08 & 0.29 \\
\hline 14 & 10 & 13.15 & 11.98 & 9.16 & -2.82 \\
\hline 28 & 10 & 18.77 & 13.54 & 13.07 & 0.47 \\
\hline 7 & 20 & 11.60 & 7.28 & 6.75 & 0.53 \\
\hline 14 & 20 & 13.15 & 8.50 & 8.35 & 0.15 \\
\hline 28 & 20 & 18.77 & 11.77 & 10.92 & 0.85 \\
\hline 7 & 30 & 11.60 & 5.66 & 6.02 & -0.36 \\
\hline 14 & 30 & 13.15 & 5.77 & 7.38 & -1.61 \\
\hline 28 & 30 & 18.77 & 9.15 & 9.74 & -0.59 \\
\hline
\end{tabular}

Table 11 shows the comparison between the compressive strength results of concretes made with substitution of cement by avocado ash and eucalyptus ash at 7,14 and 28 days of curing. For concrete mixtures made of $10 \%$ substitution of cement by wood ash, the compressive strength of avocado ash concrete showed an increase of $0.29 \mathrm{MPa}$ in 7 days, $0.47 \mathrm{MPa}$ in 28 days, and a decrease of $2.82 \mathrm{MPa}$ in 14 days comparing to eucalyptus ash concrete samples. However, at $20 \%$ of substitution, the compressive strength of avocado ash concrete showed an increase of $0.53 \mathrm{MPa}$ in 7 days, $0.15 \mathrm{MPa}$ in 14 
days, and $0.85 \mathrm{MPa}$ in 28 days comparing to eucalyptus ash concrete samples. On the other hand, at $30 \%$ of substitution, the compressive strength of avocado ash concrete showed a decrease of $0.36 \mathrm{MPa}$ in 7 days, $1.61 \mathrm{MPa}$ in 14 days, and 0.59 $\mathrm{MPa}$ in 28 days comparing to eucalyptus ash concrete samples. This let us to say that the ashes of Avocado would be the best substitute than the ashes of Eucalyptus specifically the $20 \%$ one.

\section{CONCLUSIONS}

The goal of this paper was to study the effects of $0-30 \%$ wood ashes as a substitute of cement on the strength of concretes, based on test results, the following conclusions were made:

(1) The compressive strength is a function of the type of specie of wood ash used and the percentage of ash introduced into the concrete mixture.

(2) The samples containing wood ash exhibited lower compressive strength than the control specimens, Overall, it can be seen that the introduction of wood ashes in the concrete mixtures decreased the compressive strength of concrete.

(3) The compressive strengths of $3 \%$ and $10 \%$ addition of eucalyptus ash are higher those of $5 \%$ addition of avocado ash, whereas at $5 \%$ of addition, the compressive strength of avocado ash concrete is higher than the compressive strength of eucalyptus ash concrete.

(4) At low percentages of substitution i.e. at $10 \%$ and $20 \%$, the concrete made with avocado ash give higher compressive strength than the one made with Eucalyptus ash.

(5) At higher percentage of substitution i.e. at $30 \%$, the concrete made with Eucalyptus ash give higher compressive strength that the one made with avocado ash

(6) The compressive strengths of concretes decrease with the increase of partial replacement of Portland cement with wood ash.

(7) The wood ashes have negative influence on the resistance of concrete

Overall, this paper investigates the use of wood ash in cement/concrete as a way of reducing the use and climatic impact of cement. Wood ashes from avocado and eucalyptus trees that grow in Cameroon were used. General results were that, compressive strength of cement/concrete with wood ash was lower than cement/concrete without wood ash.

It is recommended that further studies should be conducted considering samples with longer curing ages i.e. 56, 90 and 180 days of curing.

\section{REFERENCES}

[1] Bikoko, T.G.L.J., Tchamba, J.C. (2017). Filtration of fresh cement pastes. Electronic Journal of Geotechnical Engineering, 22(6): 1791-1803.

[2] Tchamba, J.C., Bikoko, T.G.L.J. (2017). Methods of determining transfer properties of fresh cement pastes, Electronic Journal of Geotechnical Engineering, 22(7): 2347-2370.

[3] Tchamba, J.C., Bikoko, T.G.L.J. (2016). Study of transfer properties on fresh cement pastes; laboratory experiments: discontinue measurements using a permeameter. Journal of Materials Science Research, 5(2): 23-32. https://dx.doi.org/10.5539/jmsr.v5n2p23
[4] Bayiha, B.N., Billong, N., Yamb, E., Kaze, R.C., Nzengwa, R. (2019). Effect of limestone dosages on some properties of geopolymer from thermally activated halloysite. Construction and Building Materials, 217: 2835. https://doi.org/10.1016/j.conbuildmat.2019.05.058

[5] Imbabi, M.S., Carrigan, C., McKenna, S. (2012). Trends and developments in green cement and concrete technology. International Journal of Sustainable Built Environment, $1(2)$ : 194-216. http://dx.doi.org/10.1016/j.ijsbe.2013.05.001

[6] Vu, V.A., Cloutier, A., Bissonnette, B., Blanchet, P., Duchesne, J. (2019). The effect of wood ash as a partial cement replacement material for making wood-cement panels. Materials, $12(17)$ : 2766. https://doi.org/10.3390/ma12172766

[7] Boden, T.A., Marland, G., Andres, R.J. (2010). Global, regional, and national fossil-fuel $\mathrm{CO} 2$ emissions. Carbon Dioxide Information Analysis Center, Oak Ridge National Laboratory, U.S. of Energy, Oak Ridge, Tenn., U.S.A. https://doi.org/10.3334/CDIAC/00001_V2010

[8] Le Quéré, C., Peters, G. P., Andres, R.J., et al. (2014). Global carbon budget 2013. Earth System Science Data, 6(1): 235-263. https://doi.org/10.5194/essd-6-235-2014

[9] Hendriks, C.A., Worrell, E., De Jager, D., Blok, K., Riemer, P. (1998). Emission reduction of greenhouse gases from the cement industry. Proceedings of the Fourth International Conference on Greenhouse Gas Control Technologies, pp. 939-944.

[10] da Luz Garcia, M., Sousa-Coutinho, J. (2013). Strength and durability of cement with forest waste bottom ash. Construction and Building Materials, 41: 897-910. https://doi.org/10.1016/j.conbuildmat.2012.11.081

[11] Humphreys, K., Mahasenan, M. (2002). Substudy 8: climate change-Toward a sustainable cement industry. An independent study commissioned by the world business council for sustainable development (WBCSD).

[12] Fernando, P.T., João, C.G., Said, J. (2010). Durability and environmental performance of alkali-activated tungsten mine waste mud mortars. Journal of Materials in Civil Engineering, 22(9): 897-904.

[13] Chowdhury, S., Mishra, M., Suganya, O.M. (2015). The incorporation of wood waste ash as a partial cement replacement material for making structural grade concrete: An overview. Ain Shams Engineering Journal, 6(2): 429-437. https://doi.org/10.1016/j.asej.2014.11.005

[14] Bikoko, T.G.L.J., Tchamba, J.C., Katte, V.Y., Amziane, S., Okonta, F.N., Tamo, T.T. (2021). Characterization of lightweight concrete impregnated with cement and Cameroonian charcoal as coarse lightweight aggregate. International Journal of Advanced Research in Engineering and Technology, 12(3): 330-365. https://doi.org/10.34218/IJARET.12.3.2021.033

[15] Bikoko, T.G.L.J., Katte, V.Y., Bawe, G.N., Fokou Dongmene, M., Okonta, F.N., Tchamba, J.C. (2019). Characterisation of lightweight concrete impregnated with cement and charcoal. Proceedings of the 3rd International Conference on Bio-based Building Materials, 26-28, RILEM Publications. Presented at the ICBBM 2019, RILEM, Belfast, UK, pp. 229-237.

[16] Bikoko, T.G.L.J., Katte, V.Y., Bawe, G.N., Fokou Dongmene, M., Okonta, F.N., Tchamba, J.C. (2019b). Characterisation of lightweight concrete impregnated with cement and charcoal. Academic Journal of Civil 
Engineering,

37(2):

229-237.

https://doi.org/10.26168/icbbm2019.33

[17] Scrivener, K.L., John, V.M., Gartner, E.M. (2018). Ecoefficient cements: Potential economically viable solutions for a low- $\mathrm{CO}_{2}$ cement-based materials industry, Cement and Concrete Research, 114: 2-26. http://dx.doi.org/10.1016/j.cemconres.2018.03.015

[18] Pehlivan, A.O., Karakuş, S., Karapınar, I.S., Özbay, A.E.Ö., Yazgan, A.U., Taşaltın, N., Kilislioğlu, A. (2020). Effect of novel synthesized nanoeggshell on the properties of cementitious composites. Journal of Advanced Concrete Technology, 18(5): 294-306. https://doi.org/10.3151/jact.18.294

[19] Tchamba J.C., Bikoko, T.G.L.J. (2016). Failure and collapse of building structures in the cities of Yaoundé and Douala, Cameroun from 2010 to 2014. Modern Applied $\quad$ Science, $\quad$ 10(1): 23-33. http://dx.doi.org/10.5539/mas.v10n1p23

[20] Neville, A.M., Brooks, J.J. (2010). Concrete Technology (2nd ed.). Longman Group, UK publishers Ltd.

[21] Schmidt, W., Otieno, M., Olonade, K., et al. (2020). Innovation potentials for construction materials with specific focus on the challenges in Africa. RILEM Technical Letters, 5: 63-74. https://doi.org/10.21809/rilemtechlett.2020.112

[22] FAO, Food Wastage Footprint Impacts on Natural Resources: Summary Report, Food and Agriculture Organisation of the United Nations, FAO, [Rome], 2013.

[23] Krausmann, F., Gingrich, S., Eisenmenger, N., Erb, K.H., Haberl, H., Fischer-Kowalski, M. (2009). Growth in global materials use, GDP and population during the 20th century. Ecological Economics, 68(10): 2696-2705. https://doi.org/10.1016/j.ecolecon.2009.05.007

[24] Steinberger, J.K., Krausmann, F., Eisenmenger, N. (2010). Global patterns of materials use: A socioeconomic and geophysical analysis. Ecological Economics, 69(5): 1148-1158. https://doi.org/10.1016/j.ecolecon.2009.12.009

[25] Udoeyo, F.F., Inyang, H., Young, D.T., Oparadu, E.E. (2006). Potential of wood waste ash as an additive in concrete. Journal of Materials in Civil Engineering, 18(4): 605-611.

[26] Wang, S., Miller, A., Llamazos, E., Fonseca, F., Baxter, L. (2008). Biomass fly ash in concrete: Mixture proportioning and mechanical properties. Fuel, 87(3): 365-371. http://dx.doi.org/10.1016/j.fuel.2007.05.02

[27] ASTMC618-15. Standard Specification for Coal Fly Ash and Raw or Calcined Natural Pozzolan for Use in Concrete American Standard Test on Materials; American Standard Test of Materials; ASTM International: West Conshohocken, PA, USA, 2015.

[28] Yang, Z., Huddleston, J., Brown, H. (2016). Effects of wood ash on properties of concrete and flowable fill. Journal of Materials Science and Chemical Engineering, 4(7): 101-114. http://dx.doi.org/10.4236/msce.2016.47013

[29] Tarun, R., Kraus, R.N., Kumar, R. (2001). Wood ash: A new source of pozzolanic material. CBU 2001-10. Munbai. 